\title{
On Some Similarities in the Status of Kashubian and Irish
}

\author{
Alina Szwajczuk \\ University of Szczecin, Szczecin, Poland
}

\begin{abstract}
The objective of the paper is to delineate apparent similarities in the status of Kashubian and the Irish language. History-wise, both languages experienced a significant language loss, a struggle for survival, and the legal attempt to keep the languages alive. In fact, both constitute minority languages while this is solely the former one that enjoys the official status of a regional language. The latter is an official language within the Republic of Ireland and the European Union. Apart from a short historical overview of the two languages, the Kashubian language will be analyzed on the basis of the Polish legislation and the reports compiled by the Council of Europe with reference to the commitments made by Poland pertaining to the implementation of provisions stipulated in Part III of the European Charter for Regional or Minority Languages. The Irish language will be viewed, within the national scope, from the perspective of the 2003 Official Languages Act, the 20-year strategy for the Irish language 2010-2030, and the 2012 Gaeltacht Act. The aspects considered herein will include mainly: the application of the languages within the judicial and administrative context, the presence of the said languages in education, as well as within the national context. The following analysis shall not be deemed as exhaustive and is solely supposed to present some similarities in history and language preservation mechanisms.
\end{abstract}

Keywords: Kashubian, Irish, legal status, language preservation strategy

\section{Introduction}

Even though the analyzed languages have no common descent with the Kashubian possessing West-Slavic roots and Irish belonging to the Gaelic branch of the Celtic languages, the two languages appear to share a similar history even though, originally, their geopolitical situations differed. Irish used to be a predominant language while Kashubian, constituting a riddle for neighbors ${ }^{1}$ who did not understand it, was the language of the Kashubian people striving for their existence in the Pomerania region.

\section{History and Language Movement Till the End of the 20th Century}

\section{The Case of Kashubian}

The factor bringing the two languages together was the national bondage that both countries ${ }^{2}$ experienced in the relatively non-distant past (Gmerek, 2010, pp. 271-272), which has exerted an enormous impact on the present linguistic circumstances of the said languages. Gmerek (2010, pp. 271-272) writes about the loss of statehood but visible maintenance of identity despite the country-specific socio-political and cultural issues.

\footnotetext{
Alina Szwajczuk, assistant lecturer, M.A., Department of English, University of Szczecin.

1 The Polish state and Germanic states (Obracht-Prondzyński \& Wicherkiewicz, 2011, p. 10).

${ }^{2}$ Kashub people are viewed as an ethnic community of Poland. Therefore, the countries referred to are Ireland and Poland.
} 
The history of the Kashub ${ }^{3}$ community is inseparable from the history of the Polish state and the German state, i.e., from the history of Pomerania. They are claimed to have appeared at their homeland territory (within the confines of the Baltic Sea in the north, the River Notec and the River Warta in the south, the River Lower Oder in the west, and the River Lower Vistula in the east) between the 5th and the 7th centuries. Since the end of the first millennium $\mathrm{AD}$, the Kashub community had constituted a subject of rivalry between the developing Polish state in the south and the Germanic state in the east. Still, the people concerned maintained their culture, language, and identity (Obracht-Prondzyński \& Wicherkiewicz, 2011, pp. 5-6).

The Kashubs constitute a community of a "long-lasting perseverance"-many social phenomena take roots in the distant past and mark on the present-day inhabitants of Kashubian: heritage of the centuries-old difficult neighborhood with the Germans, results of inhabiting a border-land area, durability of strong family ties, and devotion to religion, specific mentality and social attitudes. Of great importance is also the enduring residence in the Kashubian territory—our Homeland. (Obracht-Prondzyński, 2007, pp. 5-6)

As for the West Pomerania and Pomerania Provinces, which are the native lands of the Kashubs, their outer borders were constantly changing throughout the history as a result of migrations. This finally led to the total disappearance of the Kashubian ethnos in some parts of the region and to marginalizing the community to a minority status in others (Obracht-Prondzyński, 2007, pp. 11-12).

Following the course of the history of the 20th century, some facts significant and decisive for the Kashubian language must be mentioned. At the beginning of the century in question, Kashubs were citizens of the Prussian German state. Small Kashubian enclaves lived in Western Pomerania, with Słupsk, Bytów, Lębork, Człuchów, and Miastko being the most representative districts, while the majority inhabited Gdańsk, the main city of Pomerania. During the interwar period, however, the largest group of Kashubs lived in the 2nd Republic of Poland, the second one in the Free City of Gdańsk and the rest of the community remained within the borders of Germany. WWII was one of the most difficult periods for the Kashubs as social elites were almost entirely exterminated. As early as in fall 1939, there was a mass displacement of the Polish population from Pomerania, including Kashubs, conducted by German authorities. Besides, since March 1942, the inhabitants of Pomerania have been forced to do the military service in the German Army. The end of the war enabled the Kashubs to return to their formerly inhabited territories, mainly to the Pomeranian cities of Gdynia, Gdańsk, and Sopot (Obracht-Prondzyński, 2007, pp. 5-6). Still, Poland and Pomerania were dominated by the communist party and the Soviet Union, which was an impediment to free civic activity. Kashubian activists were subject to prosecution, including imprisonment and the Kashubian was delegitimized. The use of the term language in reference to Kashubian was forbidden. The Kashubianness and the Kashubian speech were allowed to be applied instead (Hornsby \& Wicherkiewicz, 2010, p. 3). Still, the language would not have survived if it had not been for the Kashubian language movement, both overtly expressed and covertly advocated and maintained. The first person to address the language issue was Florian Ceynowa. In his two manifestoes of 1850, he presented the situation of the Kashubs, living between Polishness and Germanness, endangered by Germanisation. Ceynowa depicted his vision of ethnic revival of the Kashubs, remaining in community with the Poles. His follower was Aleksander

\footnotetext{
${ }^{3}$ Kashubs and Kashubia are considered as denotations for the people and the region respectively (Obracht-Prondzyński \& Wicherkiewicz, 2011, p. 6).
} 
Majkowski who issued a number of papers ${ }^{4}$ and in 1912 he became the founder of Towarzystwo Młodokaszubów (The Society of Young-Kashubs). The message proclaimed by Majkowski and the Society was tantamount to the one advocated by their predecessor in a sense that everything that was Kashubian was Polish. The Society went a bit farther as, striving for the revival of the Kashubian native culture within the Polish nation, they started perceiving Gdańsk as their spiritual and economic capital. Those aspirations were stifled not only by the then authorities but also by the outbreak of WWI (Obracht-Prondzyński \& Wicherkiewicz, 2011, pp. 32-45). The year 1956, however, marked the revival of the Kashubian organization, the so called Kashubian Association, whose goal was the cultural, economic, and political development of Kashubia. In 1964, the association changed its name into Zrzeszenie Kaszubsko-Pomorskie (The Kashubian-Pomeranian Association); it published a considerable number of literary and scholarly works and issued its Pomerania journal. ${ }^{5}$ The year 1989 brought a democratic breakthrough, enhanced the Kashubian spirit and led to the promotion of the Kashub literature, introduction of the language in question to schools, the media and the Church (Obracht-Prondzyński, 2007, pp. 16-18). The 1998 administrative reform, in turn, for the first time in history, delineated the confines of the Kashubian settlement, locating it in a single administrative unit, i.e., the Province of Pomerania. The change of the state's policy towards the status of the Kashubian community led to the statutory recognition of Kashubian as the only regional language in Poland recognized officially under the Act on national and ethnic minorities and the regional language of January $6,2005 .^{6}$

\section{The Case of Irish}

The linguistic condition of Irish and the stage of devaluation it has gone through throughout the history are slightly different. From the outset, it was the indigenous language spoken in Ireland at the time of the annals of its history proper (Ó hUiginn, 2008, p. 4). The Kashubian, though spoken at the present territory of Pomerania, has never been given such an explicit status. With the already established standard used by poets in the early Modern Irish period (c. 1200-1650), Irish was the language of the vast majority of the people of the island. The early 17 th century, though, marked with the Tudor conquest and thus national bondage, changed the status of the language. As the Irish aristocracy was killed or gone into exile and much of its power, land and prestige was lost, English became the language of administration (Ó hUiginn, 2008, pp. 7-8). Soon, it became the language of a social underclass, with its status being unaltered on the eve of the Great Famine. This was also the time when there were probably more native speakers of Irish than at any time in the history of the language (Ó hUiginn, 2008, pp. 9-10). In 1841, the population numbered eight million with approximately 2.5 million of Irish speakers. The Irish itself ranked within the first 100 of the world's languages in terms of speakers. The famine killed one million, while the resultant emigration claimed another 1.5 million. The collapse of the monolingual Irish population was from $4.9 \%$ to $0.5 \%$ in 1901 (Romaine, 2006, p. 14). Though, despite the fact that those linguistic circumstances did not impede the creation of voluminous literature in Irish, English appeared as an undeniable means to progress for the

\footnotetext{
41905 - Drużba-Pismo do polskich Kaszubów (Friendship-A letter to Polish Kashubs); 1908 - Gryf (Griffin)—considered the first Polish and Kashubian social, cultural, and literary journal in West Prussia (Obracht-Prondzyński \& Wicherkiewicz, 2011, pp. 44-45).

5 The journal is still running.

6 The Law was enacted following the signing of the European Charter for Minority or Regional Languages by Poland in 2003. The role played by the external institutions, in this case being the Council of Europe, shall not be underestimated.
} 
Irish community. ${ }^{7}$ The organizations that did act for the preservation of Irish in the 19th and early 20th century were the Society for the Preservation of the Irish language and the Gaelic League. In that case, the language maintenance objective was characterized by bilingualism, not by a total reversal of the language shift. They sought for the preservation of Irish as the national language, the extension of its use as a spoken tongue, and the publication of the existing and modern literature in Irish (Ó Tuathaigh, 2008, pp. 26-27). Following the Partition settlement of 1920-1922, the Irish Free State covered the language with constitutional status of a national language, with the official recognition of English (Ó Tuathaigh, 2008, pp. 27-28). ${ }^{8}$ This declaration was not compatible with the actual linguistic situation of Irish as the 1911 census recorded only $17.6 \%$ of the Irish speaking population (Romaine, 2008, p. 18). Still, the endeavor was strengthened by the Constitution of 1937 in which Irish was declared the first official language, while the state policy objectives encompassed: the maintenance of the Gaeltachts, i.e., Irish speaking communities, the promotion and revival of the language in the overwhelmingly English-speaking country, mainly through the education system and public service (Ó Tuathaigh, 2008, pp. 27-28). Irish became an obligatory school curriculum subject at elementary and secondary level, while in the 1920s and 1930s it was a prerequisite for passing public examinations. The 1950s, however, brought about a language decline and since the 1960s, the decline accelerated. The actual implementation, though, was at odds with the official policy. The requirement of competence in Irish for entry to the public service did not guarantee an increased use of the language in the services provided to the public. Only a small part of the legislature was conducted in Irish and all branches of the state - be it the civil service, the legal system, the local government, and the security - applied mainly, if not exclusively, English. Therefore, the motivation behind language learning was not stimulated. English became the language of the majority of the Irish people as it was becoming a dominant world language. The economic crisis of the 1950s and the emigration of c. 400,000 redefined the ideological basis of the state, placing first the economic performance and growth as well as improved living standard and population retention. Ireland started to prepare the country for its accession to the former European Common Market. The 1973 membership did not entail an acknowledged official language status for Irish. Since then, the shift to the second official, and constitutionally declared language continued unabated. As the state withdrew from its role in language policy, the Irish community commenced exerting some pressure on successive governments, advocating the language rights of the Irish community. Undoubtedly, the standing taken by the state during the 1970s, 1980s, and 1990s was responsive rather than directive. It was the enactment of the Official Languages Act in 2003 that marked a new beginning and opened new perspectives for the Irish language (Ó Tuathaigh, 2008, pp. 29-38). ${ }^{9}$

\section{Present Territorial, Numerical, and Identity Aspect of the Languages in Question}

As stated above, the territory populated by the Kashub people is historically-driven and unchangeably confined to the Pomerania Province. It is estimated that in total there are approximately 500,000 people of both

\footnotetext{
7 The "language shift" was already present by the time of the act of the union of 1801 which marked the Incorporation of Ireland into the British state (Ó Tuathaigh, 2008, p. 26).

${ }^{8}$ According to Romaine (2008, p. 17), no other European state has addressed minority language issue is such a way, hoping for re-establishing it as the language of everyday life.

9 The act is discussed in detail in the further part hereof.
} 
Kashubian and partly Kashubian descent. ${ }^{10}$ In the case of Ireland, these are the so called Gaeltacht areas, established already at the beginning of the 20th century and recently redefined by the 2012 Gaeltacht Act. Currently, there are Gaeltacht areas in seven counties (Donegal, Mayo, Galway, Kerry, Cork, Waterford, and Meath). ${ }^{11}$ According to the 2011 Census, $41 \%$ of the Irish population over the age of three defined themselves as Irish speakers. The number, though, showed an increase of $7.1 \%$ on the figure in 2006.

As for the identity, it seems that in both cases respective Kasubian and Irish identity does not reflect the ability to speak Kashubian or Irish. Outside the so called Gaeltacht area, Irish is spoken as a minority language. ${ }^{12}$ The 2009 survey entitled "The Irish Language and the Irish People" shows high support for the Irish language as a token of identity, but at the same time it presents a discrepancy between the high numbers claiming knowledge of Irish and those speaking it on a regular basis. The Irish language revival, though, is visible in the growing number of gaelscoileanna (Irish-medium schools). As for the Kashubian, the situation, due to the history of the Kashubian community, is more complex. According to Obracht-Prondzyński (2007), there are four statements which depict the Kashubian identity, namely, (1) Kashubs are Kashubian; (2) Kashubs are not German (even though the history imposed forced Germainzation of Kashubs); (3) Kashubian and Polish identities are not mutually exclusive ${ }^{13}$ (though it may suggest the precedence of the Polish culture, identity, and language over the Kashubian one); and (4) Kashubian identity undergoes changes. The latter one, in fact, refers to the language meaning that it can be inherited, thoughtlessly adopted in the process of socialization in families and community, or it might be a consequence of a conscious, deliberate choice (Obracht-Prondzyński, 2007, pp. 13-15).

\section{Legally Grounded Linguistic Circumstances of Kashubian and Irish}

Even though the linguistic circumstances appear to be different, it must be admitted that, a century later, the Kashubian issue in Poland was addressed similarly to the Irish issue at the beginning of the 20th century as under the 2005 Act on national and ethnic minorities and a regional language, it was proclaimed the only officially recognized regional language in Poland. In both cases, that was the beginning of the 21 st century that introduced legal language maintenance mechanisms, protecting both the language and, to some extent, the rights of its speakers. Those are different in respective countries; though, they have a lot in common despite their different linguistic status within the European Union. Poland is a signatory to the European Charter for Minority or Regional Languages, and in reference to Kashubian, it has committed itself to follow the provisions of Part III, which introduce the language into the sphere of education, administration and justice, the media and cultural affairs. Since Irish is an official language, Ireland has not implemented the said charter; still, its Official Languages Act of 2003 applies similar mechanisms. In both cases, there exists a supervising body exerting control mechanisms over the protection of language rights. For Kashubian, these are the Council of Europe and the Minister in charge of religious denominations and ethnic minorities, while for Irish - the control function is performed by the Language Commissioner.

${ }^{10}$ Hornsby \& Wicherkiewicz (2010, p. 11) following Mordawski.

11 See http://www.coimisineir.ie/index.php?page=faoin_teanga\&tid=23\&lang=english.

12 See www.comisineir.ie./index.php?page=faoin_teanga\&tid=23\&lang=english.

13 This was also reflected in the 2006 survey conducted by Porębska and presented by Hornsby and Wicherkiewicz (2010, pp. 5-9) in which the majority of the interviewed, having been presented with the three optional answers in reference to the native language, i.e., Kashubian, both Kashubian and Polish, and Polish, chose the second option. When asked about the identity, the choices made were halved into Kashubian and Polish. 


\section{The 2005 Act on National and Ethnic Minorities and a Regional Language}

In the aftermath of signing the European Charter for Minority or Regional Languages, on January 6, 2005 Poland enacted law on national and ethnical minorities and a regional language.

The section 4 of the Act states that Kashubian is the only regional language officially recognized in Poland, stressing its territorial aspect in applying the definition provided by the Council of Europe. The Kashubs, however, are neither classified as national nor ethnic minority, while a minority language is the language of a minority. The Act provides Kashubs with the right to use and spell their first and last names in accordance with the rules of spelling of that regional language, subject to transliteration, particularly in the official register and identity documents. ${ }^{14}$ Article 8 determines the unconstrained use of the language in private and public life, the spread and exchange of information in the regional language, the run of information of a private nature in Kashubian, as well as the right to learn Kashubian or to be instructed in that language. The Article 9 of the said Act stipulates that Kashubian may be used as a supplementary language, in conjunction with the official language, in commune offices. Still, this shall only be applicable to communes where the number of speakers of Kashubian is not smaller than $20 \%$ of the total number of commune inhabitants, while the commune itself needs to be entered into the Official Register of Municipalities, at the territory of which the supplementary language is used. Besides, the communes concerned shall have the right to apply Kashub names, together with Polish ones, of places and physiographic objects. The Kashubian names are subject to approval by the Committee on Names of Places and Physiographic Objects. The opinion expressed by the Committee is further submitted to the minister in charge of religious denominations and national and ethnic minorities.

\section{The 2003 Official Languages Act}

The 2003 Official languages act pertains to the Oireachtas (the Parliament) and the courts, public bodies, the establishment of an office of the commissioner of the official languages, and place names. It is primarily targeted at ensuring better availability of public service through the medium of Irish. The rights of the public are secured in such a way that public bodies are obliged to comply with any regulation stipulated in the act in relation to the use of Irish in signage, stationery, and recorded oral announcements. The public expects to receive replies in the official language from public bodies to correspondence by post or by email written in Irish. Besides, certain key legislative documents such as financial statements, public policy proposals, or strategy statements, etc., should be published simultaneously in Irish and English. Further, a person appearing before the Houses of the Oireachtas shall enjoy the right to use Irish. Official reports following debates and other proceedings must be published bilingually in English and in Irish. Both, the said translation and simultaneous interpretation system are to provide firm legal footing for Irish speakers, and not to put at a disadvantage any person without Irish. As the acts of the Oireachtas, together with the Constitution, constitute the primary source of law in Ireland, and following 2006 they must be printed and published simultaneously in both official languages after their enactment.

14 The Article 7 of the Act on national and ethnic minorities and a regional language. 


\section{Ramifications of the Said Acts and Legislature With Regard to Education, Legal Context, and Administration}

\section{Educational Aspect}

The basic reservation within the educational aspect of Kashubian voiced by the Council of Europe is that it constitutes an optional subject, and there are no schools where subjects are taught through the medium of Kashubian. Further, despite numerous attempts, the Kashubian studies have not been established at the tertiary education level due to a small number of interested parties. ${ }^{15}$ The significant aspect, though, which may not remain unaddressed, is the existence of the Kashubian Language Board (Rada Języka Kaszubskiego ${ }^{16}$ ) which deals with determining the written standard of the language. ${ }^{17}$ By the review of the Kashubian vocabulary, and most importantly, by its enrichment presented in a number of bulletins, the Kashubian language is kept alive. In Ireland, Irish is a compulsory primary and secondary school subject. However, there exists c. 200 Irish-medium schools, and the language is also present at the post-secondary education level. Still, as stated above, the number of people studying Irish does not correspond with the ability to speak the language and the actual use of the language in everyday life.

\section{Legal Context}

The commitment made by Poland, ${ }^{18}$ in reference to the use of Kashubian in court, is stipulated by the Act on the Polish language (Article 2.2) which confirms the validity of legal documents in Kashubian. Nonetheless, there are not any particulars within the reports of the Council of Europe on the implementation of the charter, which might confirm the use of Kashubian at court. The situation in Ireland, in this respect, is similar in a sense that either of the two official languages may be used in court, in any pleading in any court, and in any document issuing from any court. This is the obligation imposed on the court that ensures that any person may be heard in the official language of his/her own choice. ${ }^{19}$

\section{Administration}

The Act on National and Ethnic Minorities and on the Regional Language states that the regional language may be used in contacts with local authorities of municipalities where the population of Kashubian people amounts to $20 \%$ of the total population figure of a given municipality according to the census of 2002. In such municipalities, the people concerned are permitted to address both in writing and orally, and upon a request, receive a written or oral reply in Kashubian, with one reservation that the appeal procedure must be carried out in Polish. Still, the auxiliary language might be applied only at the local level, with no possibility of using it in contact with powiat (district) or województwo (province) authorities. The same applies to the use of place names in Kashubian, as in this case also the $20 \%$ threshold of Kashubian population within a given municipality is required. Still, within the municipalities where the population of Kashubs does not reach $20 \%$ of the total population within a municipality, the local council may, on the basis of consultations held, adopt place names in

\footnotetext{
15 Data binding in 2013.

16 The Board was established in the aftermath of the enactment of the 2005 Act and the strategy for the protection and development of the Kashubian language and culture.

${ }^{17}$ Kashubian, unlike Irish, is undergoing the process of having its written standard established.

18 Article 9 of the European Charter for Minority or Regional Languages with regard to Kashubian.

${ }^{19}$ See www.coimisineir.ie/index.php?page=gaeilge_sna_cuirteanna\&lang=english\&tid=35.
} 
Kashubian in conjunction with Polish names in certain parts of the municipality where a majority of voters supported the bilingualism of place names. In Ireland, the situation resembles that of Kashubian in a sense of the administrative boundaries imposing certain obligations. Within the Gaeltacht areas, Irish is used as the language of administration while place names are provided solely in that language. In the rest of the country, an equal status is given to both languages.

\section{Language Maintenance and Promotion Strategies}

The Kashub community and Ireland possess acts that specify the language status and both possess strategies that are meant to act as language promotion and maintenance vehicles.

The 2006 Strategy for Protection and Development of the Kashubian Language and Culture and the 20 Year Strategy for the Irish Language strive to make respective languages capable of existence and development. The objectives, common for both strategies, are, among others, mainly the education of and in the two languages from the early age, with a particular emphasis placed on the family-based transmission of the language. Both advocate the use of the language in the media, cultural activities, and social life, and both see the language development through the publication of dictionaries and vocabulary enrichment. They also strive for recognition, not only at the national but also at the international level.

\section{Conclusion}

Apparently, with two different linguistic descents, completely different language national, international, and actual status, Kashubian and Irish possess similar history, marked with the language decline, similar language movements, and confinement. They share the sense of national and ethnic identity and possess similar language protection and preservation strategies. The article touched solely upon the surface of resemblance between the said languages, from the perspective of the historical and legislative ground. Therefore, it did not cover the thorough analysis and polemics with regard to the issue of minority languages within the European context conducted, among others, by Hornsby and Agarin (2012), Wicherkiewicz (2011), and Craith (2006).

\section{References}

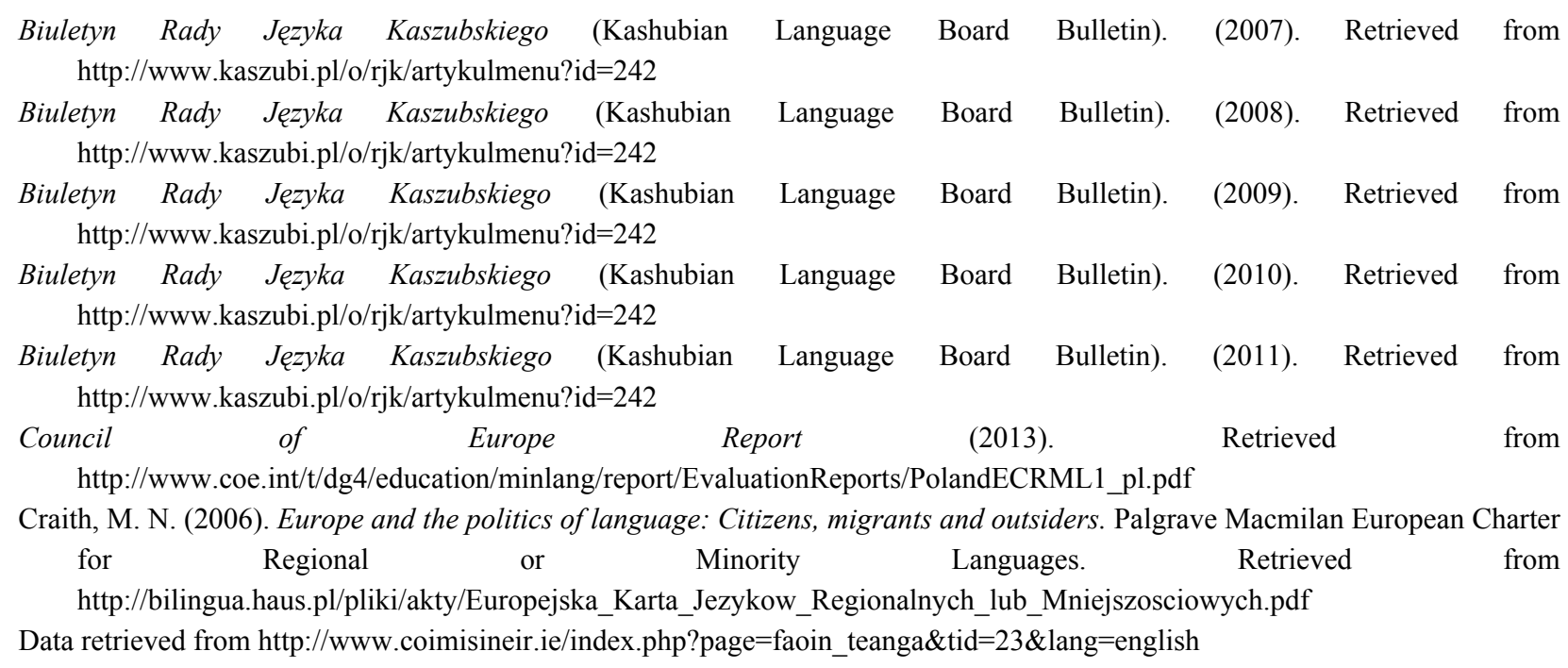


Data retrieved from www.coimisineir.ie/index.php?page=gaeilge_sna_cuirteanna\&lang=english\&tid=35

Gmerek, K. (2010). Polacy i materia celtycka $w$ XIX wieku (The Poles and the Celtic matter). Poznań: BONAMI Wydawnictwo-Drukarnia.

Hornsby, M., \& Agarin, T. (2012). The end of minority languages? Europe's regional languages in perspective. Journal of Ethnopolitics and Minority Issues in Europe, 11(1), 88-116.

Hornsby, M., \& Wicherkiewicz, T. (2010). To be or not to be (a minority)? The case of Kashubian in Poland. Retrieved from http://193.16.218.161/uploads/rendezvenyek/mineureg/eloadasok/Wicherkiewicz_Hornsby.pdf

Mordawski, J. (2005). Statystyka ludności Kaszubskiej. Kaszubi u progu XXI Wieku (Statistics on the Kashubian population. Kashubs on the eve of the 21 st century). Gdańsk: Instytut Kaszubski.

Ó hUiginn, R. (2008). The Irish language. In N. P. Caoilfhionn and S. Ó Cearnaigh (Eds), A new view of the Irish language. Dublin: Cois Life Teoranta.

Ó Tuathaigh, G. (2005). Language, ideology and national identity. In J. Cleary and C. Connolly (Eds.). (2008), The Cambridge companion to modern Irish culture. Cambridge: Cambridge University Press.

Ó Tuathaigh, G. (2008). The state and the Irish language. In N. P. Caoilfhionn and S. Ó Cearnaigh (Eds.), A new view of the Irish language. Dublin: Cois Life Teoranta.

Obracht-Prondzyński, C. (2007). Kaszubi dzisiaj. Kultura-język-tożsamość (The Kashubs today: Culture, language, identity). Gdańsk: Instytut Kaszubski.

Obracht-Prondzyński, C. (2007). The Kashubs today: Culture-language-identity. Gdańsk: Instytut Kaszubski. Retrieved February 24, 2014 from http://www.instytutkaszubski.pl/pdfy/angielski.pdf

Obracht-Prondzyński, C., \& Wicherkiewicz, T.(Eds). (2011). Nationalism across the globe, Volume 2: Kashubs: Past and present. Oxford, Bern, Berlin, Bruxelles, Frankfurt am Main, New York, Wien: Peter Lang AG.

Porębska, M. (2006). Das Kaschubische: Sprachtod oder Revitalisierung?: Empirische Studien zur ethnolinguistischen Vitalität einer Sprachminderheit in Polen (Kashubian: Language death or revitalization? Empirical research concerning ethnolinguistic vitality of the linguistic minority in Poland). Munich: Verlag Otto Sagner.

Romaine, S. (2006). Planning for the survival of linguistic diversity in language policy. In N. P. Caoilfhionn and S. Ó Cearnaigh (Eds.). (2008), A new view of the Irish language. Dublin: Cois Life Teoranta Rules of the Kashubian Language Board. Retrieved from http://www.skarbnicakaszubska.pl/dokumenty/akty_prawne/Regulamin\%20RJK.pdf

Ustawa z dnia 6 stycznia 2005 r. o mniejszościach narodowych i etnicznych oraz o języku regionalnym (Act on national and ethnic minorities and the regional langauge). (2005). Retrieved from http://isap.sejm.gov.pl/DetailsServlet?id=WDU20050170141

Wicherkiewicz, T. (2011). Języki regionalne w Europie Środkowo-Wschodniej—nowa jakość w polityce językowej, nowy wymiar tożsamości (Regional languages in the Central and Eastern Europe-A new quality in the language policy, a new dimension of identity). In I. Koutny and P. Nowak (Eds.), Language communication information. Poznań: Rys. 